\title{
I Want to Teach in the Regional Areas: A Qualitative Study about Teachers' Career Experiences and Decisions in Regional Australia
}

\author{
Luis Miguel Dos Santos
}

Woosong University, 196-5 Jayang Dong, Daejeon 34514, South Korea

DOI: https://doi.org/10.36941/jesr-2021-0103

Abstract

The Australian government seeks to develop regional and rural communities and school systems. One of the challenges would be the human resources and workforce for registered and qualified teachers, particularly in the field of Languages Other Than English (LOTE). Based on social cognitive career theory (Dos Santos, 2021a; Lent et al., 1994), this study focused on the career perspectives and career decision-making processes of registered and qualified teachers in the field of Languages Other Than English (LOTE). The following research question guided the direction of this study, why would registered and qualified teachers in the Languages Other Than English (LOTE) field (i.e. foreign languages) decide to move to Australian regional and rural communities to develop their teaching career? With the general inductive approach, 18 participants were invited for the interview sessions and focus group activities. The results of this study indicated that missions and goals for development in the regional and rural communities and governmental encouragement for regional and rural developments are the two personal consideration elements. The sharing and comments become a blueprint for government agencies, school leaders, and policymakers to reform the current human resources plans and schemes to attach additional workforce to the regional and rural communities, particularly for teachers.

Keywords: Australia, human resources management, regional development, regional school, rural school, school system, social cognitive career theory, teacher's professional development, teacher's workforce, workforce

\section{Introduction}

Human resources shortages are a significant problem in school management. Unlike other occupations where individuals may join the profession without particular training and licenses, individuals are required to register and complete appropriate professional training to teach at preschool, primary school, secondary school, and senior secondary school in Australia (The Australian Education System: Foundation Level, 2020). Traditionally, undergraduate students must complete their Bachelor of Education degree with appropriate internship experiences in a school setting in order to receive the qualification to teach. However, those who turn to teaching after a career change may complete a Master of Teaching degree with the same academic and internship requirements in order to obtain their qualification. No one may teach in the Australian school system without at least a bachelor's degree in the relevant subject matter. 
According to the Queensland Government Department of Education (High Demand Teaching Areas, 2021), there are three high priority disciplines in the Queensland school system. The first area includes the Science (e.g. biology, chemistry, physics), Technology (e.g. industrial design and technology, including manual arts), Engineering (e.g. robotics), and Mathematics. The second area includes primary education (e.g. in the rural and remote communities, special education, and foreign language studies). The third area includes secondary education (e.g. special education, industrial design and technology, foreign language studies, and senior English).

Although fresh graduates, pre-service teachers, and second-career teachers are graduating from university every year (Buchanan \& Buchanan, 2017; Cuervo \& Acquaro, 2018; Dos Santos, 2019a, 2019c, 2019e; Glutsch \& König, 2019), there are still shortages of qualified teachers in the Australian school system. A recent report (Henebery, 2020) indicated that more than 30\% of Australian teachers are likely to leave the profession after a few years of services (Weldon, 2018). Although state and federal governments have established plans and support schemes from the school to the federal level, teachers continue to leave the profession, particularly in rural and remote communities. In order to encourage teachers from urban communities to take posts in rural and remote regions, the government announced the National Exceptional Teaching for Disadvantaged Schools (NETDS) programme (Patty, 2021). Currently, the New South Wales Department of Education employs nearly 75 , ooo teachers in the public school system and is seeking to recruit for almost 1,300 permanent positions. Although support plans and vacancies are always available, the human resources gaps will not be filled in the near future.

A certain level of turnover in the teacher population is normal as teachers seek to move to another teaching environment or promotion (Ingersoll, 2001; Odland \& Ruzicka, 2009). Also, retirement is not uncommon in the teaching profession. However, the turnover and attrition rates are higher than those of new recruits. A recent study (Weldon, 2018) indicated a tendency for between $30 \%$ and $50 \%$ of Australian teachers to leave the profession after five years. Another (Cuervo \& Acquaro, 2018) indicated that teachers from regional and rural communities are more likely to return to the regional school system to pursue their career development. Besides the regional and rural backgrounds of the teachers, a previous study (White et al., 2011) indicated that university might coordinate with the regional and rural communities and school systems for internships and practicum experiences. Some pre-service teachers in urban areas have no experience of life in rural communities. They are unlikely to enter such communities without solid reasons. However, suppose their university arranged internships and teaching and learning experiences for pre-service teachers during their university journey. This could encourage them to seek or accept regional and rural teaching posts after graduation (Goodnough \& Mulcahy, 2011). The rural internship is a successful solution for human resources gaps and problems. A recent study (Dos Santos, 2019d) investigated the coordination between a university health department with an internship site in a rural community. The students expressed their interest in developing their career in a rural community due to their positive experiences. Somerville et al. (2010) further advocated that schools, teachers, students, and parents should not reject the regional and rural school systems as unique or abnormal. It is important to provide additional opportunities for pre-service and in-service teachers and school professional staff to understand the context of the regional and rural school systems in order to reduce misunderstanding, bias and discrimination.

The social cognitive career theory is the theoretical framework for this study. The social cognitive career theory is one of the useful theories for the understanding, perspectives, and decision-making process of individuals' career intentions and behaviours (Dos Santos, 2021a; Lent et al., 1994). The social cognitive career theory is developed by Lent et al. (Lent et al., 1994) based on the developments and guidelines from Bandura's self-efficacy approach (Bandura, 1982) and social cognitive theory (Bandura, 1988, 1991). The original social cognitive theory by Lent et al. (Lent et al., 1994) concerned 
the relationships of personal determinants, environmental determinants, behavioural determinants. However, due to the social and cultural developments of the career background and society, many scholars enhanced and reformed the social cognitive career theory with additional information, ideas, and factors. Currently, the study employed the updated version of the social cognitive career theory by Dos Santos (Dos Santos, 2021a; Lent et al., 1994) as the tool for the investigation. Based on the current version of the social cognitive career theory, five elements may influence individuals' career perspectives and behaviours, as the following:

- Interest in career development

- Personal considerations

- Financial considerations

- Academic interest

- Achievement of education and career goals

Each factor and element may or may not influence by each other. In other word, individuals' career perspectives and behaviours can be influenced exclusively by a single factor. However, multiple factors and elements may influence people's behaviours as well. Please refer to Figure 1 for the details of the theoretical framework.

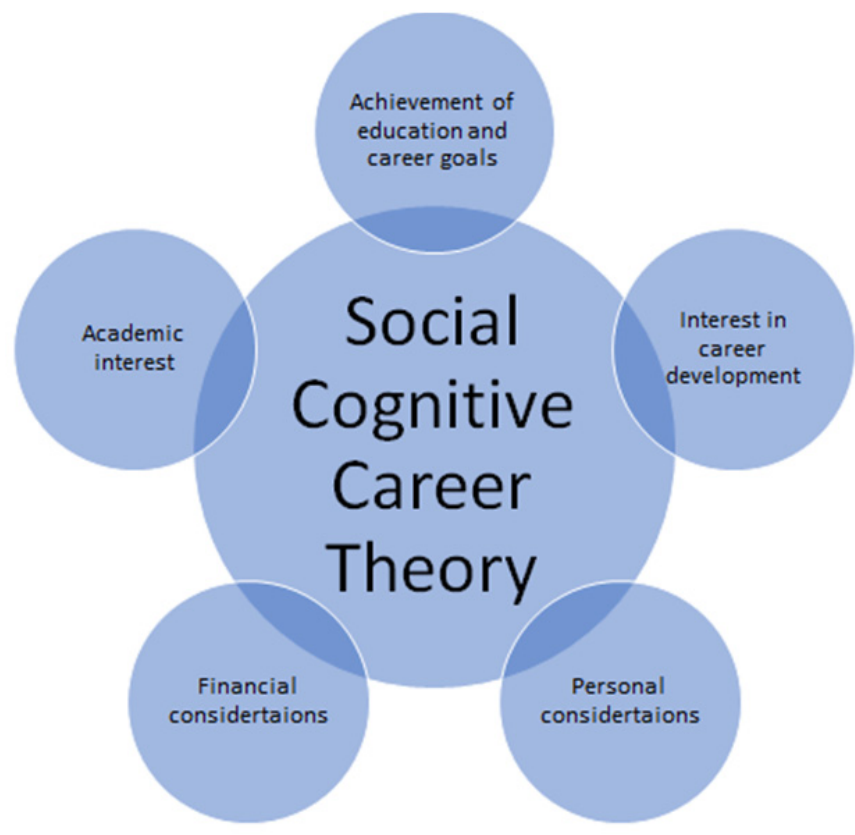

\subsection{Purpose of the Study}

Based on social cognitive career theory (Dos Santos, 2021a; Lent et al., 1994), this study focused on the career perspectives and career decision-making processes of registered and qualified teachers in the field of Languages Other Than English (LOTE). The following research question guided the direction of this study:

1. Why would registered and qualified teachers in the Languages Other Than English (LOTE) field (i.e. foreign languages) decide to move to Australian regional and rural communities to develop their teaching career? 


\section{Methodology}

The general inductive approach (Thomas, 2006) was employed for this qualitative inquiry. The general inductive approach is a useful qualitative methodology for research studies with the inductive direction. Unlike other qualitative research methodologies with some particular restrictions and background setting, research studies with the application of the general inductive approach may collect qualitative data in the basic qualitative requirements. For the current study with the aims for qualified Languages Other Than English (LOTE) (i.e. foreign language) teachers who cannot find teaching opportunities all across the Australian states and territories, particularly in the Australian regional areas. The general inductive approach is appropriate as this study's locations and external setting was wide and massive.

\subsection{Participants and Recruitments}

The snowball sampling strategy (Creswell, 2014) was employed to recruit the participants for this study. First of all, the researcher invited three registered and qualified teachers who are specialised in Languages Other Than English (i.e. foreign language) teaching and learning in Australia. The researcher contacted them and sent the research protocol, research rationale, interview questions, procedures, and related materials to the participants via email. If the participants want to join, the participants may contact the researcher and transfer the signed agreement form to the researcher for the arrangement, particularly the interview session(s). For the first round, three participants agreed with the participation and signed the agreement for the study.

Second, due to the COVID-19 Pandemic and lockdown policy from the Australian government, the researcher could only conduct one-on-one and semi-structured interview via Zoom. After the first three interview sessions, the participants referred additional participants who met the criteria for participation. As a result, a total of 18 participants were willing to join and share their experiences. The participants must meet the following points for participation, as the following,

- Registered as a qualified teacher under one of the Australian states and territories department, college, or organisation

- Specialised in Languages Other Than English (LOTE) (i.e. foreign language)

- Have sought, currently seeking, or current teaching for teaching positions at their targeted school background and level

- Target the regional and rural schools as their destination

- At least 18 years old

- Non-vulnerable people

Third, after all participants completed the one-on-one and semi-structured interview session(s) with each participant, the researcher invited all participants for the focus group activities in order to collect additional sharing and lived stories as groupmates. Three focus group activities (i.e. six participants per group) were formed via Zoom or Whatsapp.

\subsection{Data Collection}

The one-on-one and semi-structured interview was the main data collection tool. The researcher arranged the distance-based semi-structured interview sessions via Zoom or Whatsapp based on the requirements of the participants. During the interview sessions, the researcher used a digital recorder to record the voice messages. However, no visual data could be recorded. All participants agreed with this arrangement. Each interview session lasted from 56 to 71 minutes. After the interview session, the researcher reminded the referral request(s) for any potential participants.

Second, during the focus group activities, the researcher served as the coordinator for the interview questions. The participants shared and guided their own lived stories, comments, and 
opinions based on the interview questions and research questions. Each focus group activity lasted from 71 to 99 minutes.

After the procedures of the semi-structured interview sessions and focus group activities, the researcher transcribed the voice messages to written transcripts for data analysis. Once the voice messages were transcribed, the researcher requested a member checking interview for each participant in order to confirm their lived stories, comments, and opinions. The member checking interview lasted from 34 to 45 minutes. All participants confirmed and agreed with their own data.

\subsection{Data Analysis}

The researcher re-read the transcripts and data multiple times in order to categorise the themes and directions. First, the researcher employed the open-coding technique (Strauss \& Corbin, 1990) to categorise the massive data into meaningful groups and themes. As for the first-level themes and subthemes, the researcher grouped 11 themes and 13 subthemes. However, qualitative researchers (Creswell, 2014; Merriam, 2009; Tang \& Dos Santos, 2017) indicated that further steps should be followed. Therefore, the researcher employed the axial-coding technique (Strauss \& Corbin, 1990) for further development. As a result, two themes and three subthemes were merged.

\subsection{Human Subject Protection}

The privacy of the participants is the most important factor in this study. As the regional and rural Australian school systems are not large, the lived stories, comments, and opinions can be captured by school leadership. Therefore, the researcher needed to exercise all ways to protect the personal information of each participant. First of all, each participant was given a pseudonym to mask their identity. Second, the signed agreements, personal information, contacts, voice messages, written transcripts, computer, and related materials were locked in a password-protected cabinet. Only the researcher has the rights to read the materials. After the researcher completed the study, the researcher deleted and destroyed the materials immediately in order to protect privacy for all parties. The current study was supported by the Woosong University Academic Research Funding 2021.

\section{Results and Discussions}

Semi-structured interview sessions and focus group activities allowed the researcher to collect rich and meaningful data from the participants. Each participant shared their experiences, comments and opinions about their career perspectives, career decision-making process and experiences in Australian regional and rural communities. Although all the participants have different backgrounds, university experiences, expertise, skills, and understanding, some aspects of their experiences and sharing were similar. The researcher could thus group their experiences, comments and opinions into two themes and three subthemes (see Table 1).

Table 1: Themes and Subthemes

\begin{tabular}{|l|l|}
\hline \multicolumn{2}{|c|}{ Themes and Subthemes } \\
\hline Missions and Goals for Development in the Regional and Rural Communities \\
\hline \multicolumn{2}{|c|}{ Children in Regional and Rural Communities Should Have Social Equality } \\
\hline Governmental Encouragement for Regional and Rural Development \\
\hline \\
\hline
\end{tabular}




\subsection{Missions and Goals for Development in Regional and Rural Communities}

...students in all environmental backgrounds...should have their rights for learning...their school and home locations...are the restrictions...for excellent school education...we need to find out the ways...to offer the right education and support...for children the rural communities in Australia...Australia needs to have good support for our children...we are here to provide the education...(Participant \#1, Interview)

According to some previous studies (Petrin et al., 2014; Weiner, 2012; Weiner \& Jerome, 2016), although urban, suburban and rural school systems face the same shortages of registered teachers and school professional staff, rural school systems often struggle to recruit due to the remote locations involved and the lack of essential support for teachers' families and teaching strategies. In fact, many teachers are willing to move to regional and rural communities for work (Halsey \& Drummond, 2014), but those with families face the same problems for their children, particularly the lack of teaching and learning support (Yi et al., 2018). As most of the participants were single individuals and fresh university graduates, many do not need to consider such matters. The researcher captured the following comments and opinions:

...I think Australian people should have the missions and goals for the rural school development...we enjoyed the urban developments for many years...but what about the children in the rural communities...they are all Australian people too...I think children in the rural communities should have the opportunities to learn foreign languages too...not just the children in the urban or private schools...(Participant \#13, Interview)

...Australia is a large country...we have a lot of regional areas and towns...many of these towns are recruiting different people, skilled workers, and professionals...for the economic developments...they have children and their children need to go to school...but if their children...cannot receive excellent education...they are going to leave and go back to the urban...I want to become one of the few groups...for foreign language teaching in the regional schools...(Participant \#12, Focus Group)

Many participants believed that the location of schools should not be a restriction for foreign language teaching. As shown by a previous study (Dos Santos, 2018), although foreign language teaching is not one of the most important subjects in the current Australian school system, students in regional and rural communities should have opportunities to learn a foreign language (Simpson \& Wigglesworth, 2019). Based on social cognitive career theory (Dos Santos, 2019e, 2021a, 2021b; Lent et al., 1994; Lent \& Brown, 1996), the factor of personal consideration for developing the regional and rural school systems is noted and reflected. In other words, most of the comments and opinions from the participants fell into this category. A recent study (Ushioda \& Dornyei, 2017) indicated that many students are interested in learning foreign languages. Most participants noted that Languages Other Than English (LOTE) subjects were not available in the regional and rural school systems, and they wanted to work in these communities.

\subsubsection{Children in Regional and Rural Communities Should Have Social Equality}

Besides children's opportunities to learn foreign languages, many participants spoke about social equality for regional and rural communities. According to a recent study (Gerrard et al., 2017), the government contributes appropriate funding and resources for different support structures in regional and rural school systems. In fact, financial resources are established, but there is still a shortage of teachers who want to work in them. However, the participants went the other way due to personal considerations of children's social equality. Several interesting comments were captured:

...social equality is one of the most important subjects and projects for our Bachelor's degree programme...we always take about this topic at school and course...students, including university students, should enjoy the excellence of education...therefore, I can come to this university for 
education...at the same time, children should enjoy the social equality too...as the Australian government provides me this opportunity for education...I have to go back to the regional school systems...for the return...(Participant \#9, Interview)

...I believe we need to have social equality for all people in Australia...Australian children need to have good education...they need to receive equal education...and quality... regardless of their living places...I am still young, and I can provide my energy to the children in the regional school systems...I cannot promise for decades...but for the coming years...I am sure...regional schools will be my place...(Participant \#5, Focus Group)

Some teachers spoke about how regional and rural communities should welcome new immigrants and teachers with different cultural backgrounds in order to meet the expectations for intercultural communication and cultural perspectives (Halsey \& Drummond, 2014). Australia is a multicultural country with residents from all over the world. Students in regional and rural communities should encounter global citizens at an early age in the interests of their social and cultural developments (Sakurai et al., 2010). The researcher captured several interesting comments:

...I am an immigrant to Australia...as these children may need to go to another country for business and job opportunities in the future...I think my cultural experiences and stories can...inspire their horizon...and thinking of their university major and job after school...students in the metropolitans can work with a lot of these people...but I want to become the one who can...come to regional Australia for this exchange...(Participant \#6, Interview)

...so many Australian people are going to southeast Asia for a holiday...but some of them do not understand the religious practices and languages in this part...not only languages...I want to teach the religious and cultural materials to the students...for example, how to talk to Asian people and why some Muslim girls need to wear their scarf...(Participant \#8, Focus Group)

In conclusion, the comments and opinions of the participants show that personal considerations play an important role in their career perspective and career decision-making processes (Dos Santos, 2021a; Lent et al., 1994; Lent \& Brown, 1996). Echoing a recent study (Dos Santos, 2019b), all the participants expressed their concerns about social equality and their mission to teach children in regional and rural communities. In line with social cognitive career theory (Dos Santos, 2021a; Lent et al., 1994), the researcher can confirm that career decisions are closely connected to personal considerations.

\subsection{Governmental Encouragement for Regional and Rural Development}

For more than three decades, the Australian government has sought to develop regional and rural communities as most people tend to stay in urban and metropolitan areas for financial, economic and personal reasons (Krivokapic-Skoko et al., 2018). However, within the last decade, the Australian government established plans and encouraged Australians, immigrants, international students and visa workers to develop their career in regional and rural communities (Hay et al., 2017; Russell et al., 2017). Although governmental policies are established, the results are not significant. The government should understand the reasons why people do not want to move to regional and rural communities, and the following outlines the reasons. One interesting comment was captured:

...I want to go to the remote school system because the government encourages us...also, it is very hard for me to find a teaching position in the urban school system...because I am not a White Australian person...many of the positions are reserved for the White people... as a colour person...I can only move to the rural community...(Participant \#3, Focus Group) 


\subsubsection{Demand for Languages Other Than English (LOTE) Subjects}

Due to the active skilled visa programmes, such as the skilled independent visa subclass 189 programme, skilled workers and professionals worldwide may immigrate to Australia for career and personal development. As a result, intercultural communication and interaction are needed for local Australian children and adults (Ling \& Tran, 2015). Moreover, due to globalisation, it is necessary to interact with people of different cultures for business, personal, educational, and economic development. Therefore, foreign language skills and cultural understanding are essential for future generations. All participants expressed their concerns about the knowledge and educational demands of foreign language teaching and learning in regional and rural communities and school systems. The researcher captured some comments:

...if children can learn foreign languages during their early childhood...they can understand the language better...also when children can interact with people.... with different cultural and language background, it will be...beneficial to their value and learning...(Participant \#2, Interview)

...it is useful if our students can speak multiple languages...in our university and cities...we have a lot of international expats, students, and professionals on the street...they all speak different languages and have different cultural understanding...I think it is important...for Australian people to have multiple language skills...to provide services to people from different parts of the world...(Participant \#4, Focus Group)

...some nursing students and programmes required their students to have foreign language skills for graduation...it is good because medical professionals should speak the patients' language...for better medical understanding and services...for example, pain, what types of pain...if the medical professionals can speak the language, no immediate translators are needed...(Participant $\#_{14}$, Interview)

In short, many were concerned about the cultural and language diversity in regional and rural communities and schools (Halsey \& Drummond, 2014). A recent study (Chang \& Chan, 2020) about the transitional points for social and cultural development found that students who gain social and cultural understanding during their study period are more likely to be successful in the future. The participants in this study echoed this and chose to pursue their career in the regional and rural school systems.

\subsubsection{Previous Connections with Regional and Rural Communities}

Last but not least, some participants spoke of their experiences in their student teaching internship or university experiences in regional and rural communities and school systems. Previous studies (Adams \& Woods, 2015; Dos Santos, 2019b, 2019d, 2019e; Pit \& Hansen, 2014) have found that teachers and school professional staff with previous experience in regional and rural communities are more likely to pursue their career in such areas. Therefore, if university departments can coordinate with regional and rural schools, pre-service teachers and school professional staff may enter these areas after graduation. One interesting comment was captured:

...I want to return to the regional school...because I completed my student-teaching internship here...so that's why I am going to teach here...I used to live in the big cities before...but this student-teaching internship...asked me to come over here for two months...I enjoyed it...and I can see they want to have a Spanish [LOTE] teacher...I am going to start my job here!...(Participant \#10, Interview)

In conclusion, personal considerations, as predicted by social cognitive career theory (Dos Santos, 2021a; Lent et al., 1994), took the most important role in these participants' career perspectives and career decision-making process. Although five factors are listed by the theory, they did not feature significantly in the participants' comments. Although the researcher asked 
interviewees questions about other factors in the theoretical framework, such as how financial considerations influenced their career perspectives, most asserted that money was not their priority (Gibbons \& Shoffner, 2004). Personal considerations are one of the most important factors in terms of career development and human resources and workforce management in rural school systems (Dos Santos, 2019b).

\section{Limitations and Future Research Developments}

The current study focused on regional and rural school systems in Australia. However, other school systems in Oceania face the same problems, including human resources shortages. Therefore, future research may extend the sample to teachers and school professional staff in other countries and regions within Oceania.

The current study only collected data from registered and qualified teachers with a specialisation in foreign languages. Other subjects, such as STEM and primary education, face the same human resources shortages. Therefore, future research should extend the focus to other indemand subjects and fields in order to develop a holistic picture of the current situation.

Last but not least, the current study only collected data from participants interested in teaching in regional and rural areas. However, many teachers decide to leave the regional school system for an urban school. Therefore, dual interview sessions drawing thoughts from both sides should be considered.

\section{Conclusion and Implications}

The study can be contributed to the current practices in school's human resources management. First, with the guideline of the social cognitive career theory, the school leaders coordinate with some local university department of education the development of student-teaching internship programmes. As most of the participants advocated that personal consideration is their significant factor for regional and rural school teaching, the results may reflect other students with similar backgrounds.

Second, although financial consideration is not a significant factor for these groups of participants, other pre-service and in-service teachers may consider salary as their element, particularly individuals with family members. Therefore, special stipends for regional and rural school systems and teachers may be useful.

In conclusion, this study outlined the motivations and reasons why registered and qualified teachers in the Languages Other Than English (LOTE) field (i.e. foreign languages) decide to move to Australian regional and rural communities for teaching. The sharing and comments become a blueprint for government agencies, school leaders, and policymakers to reform the current human resources plans and schemes in order to attach additional workforce to the regional and rural communities, particularly for teachers.

\section{References}

Adams, B. L., \& Woods, A. (2015). A model for recruiting and retaining teachers in Alaska's rural K-12 schools. Peabody Journal of Education, 9o(2), 250-262. https://doi.org/10.1080/0161956X.2015.1022115

Bandura, A. (1982). Self-efficacy mechanism in human agency. American Psychologist, 37(2), $122-147$. https://doi.org/10.1037/0003-066X.37.2.122

Bandura, A. (1988). Organisational applications of social cognitive theory. Australian Journal of Management, 13, 275-302.

Bandura, A. (1991). Social cognitive theory of self-regulation. Organisational Behavior and Human Decision Processes, 50, 248-287.

Buchanan, K., \& Buchanan, T. (2017). Relationships with families: Have educators overlooked a critical piece of the puzzle? Improving Schools, 20(3), 236-246. https://doi.org/10.1177/1365480216674622 
Chang, C.-W., \& Chan, S.-J. (2020). Transit point of global talent: Social/cultural dimensions of short-term student circulation. Globalisation, Societies and Education, 18(1), 30-42. https://doi.org/10.1080/14767724.2019.1690731

Creswell, J. (2014). Research design: Qualitative, quantitative, and mixed methods appraoches (4th ed.). Sage.

Cuervo, H., \& Acquaro, D. (2018). Exploring metropolitan university pre-service teacher motivations and barriers to teaching in rural schools. Asia-Pacific Journal of Teacher Education, 46(4), 384-398. https://doi.org/10.108o/1359866X.2018.1438586

Dos Santos, L. M. (2018). Foreign language learning beyond English: The opportunities of One Belt, One Read (OBOR) Initiative. In N. Islam (Ed.), Silk Road to Belt Road (pp. 175-189). Springer.

Dos Santos, L. M. (2019a). Engineering education as a second career: The experience of female practising engineers. Global Journal of Engineering Education, 21(3), 202-207.

Dos Santos, L. M. (2019b). Investigating employment and career decision of health sciences teachers in the rural school districts and communities: A social cognitive career approach. International Journal of Education and Practice, 7(3), 294-309. https://doi.org/10.18488/journal.61.2019.73.294.309

Dos Santos, L. M. (2019c). Mid-life career changing to teaching profession: A study of secondary school teachers in a rural community. Journal of Education for Teaching, 45(2), 225-227. https://doi.org/10.1080/02607476.2018.1548168

Dos Santos, L. M. (2019d). Rural public health workforce training and development: The performance of an undergraduate internship programme in a rural hospital and healthcare centre. International Journal of Environmental Research and Public Health, 16(7), 1259. https://doi.org/10.3390/ijerph16071259

Dos Santos, L. M. (2019e). Recruitment and retention of international school teachers in remote archipelagic countries: The Fiji experience. Education Sciences, 9(2), 132. https://doi.org/10.3390/educscigo20132

Dos Santos, L. M. (2021a). Developing bilingualism in nursing students: Learning foreign languages beyond the nursing curriculum. Healthcare, 9(3), 326. https://doi.org/10.3390/healthcare9030326

Dos Santos, L. M. (2021b). Motivations and experiences in a distance learning-based degree programme: A case study from a community college. Academic Journal of Interdisciplinary Studies, $10(2), 35$. https://doi.org/10.36941/ajis-2021-0036

Gerrard, J., Savage, G., \& O'Connor, K. (2017). Searching for the public: School funding and shifting meanings of 'the public' in Australian education. Journal of Education Policy, 32(4), 503-519. https://doi.org/10.1080/02680939.2016.1274787

Gibbons, M. M., \& Shoffner, M. F. (2004). Perspective First-Generation College Students: Meeting Their Needs Through Social Cognitive Career Theory. Professional School Counseling, 8(1), 91-97.

Glutsch, N., \& König, J. (2019). Pre-service teachers' motivations for choosing teaching as a career: does subject interest matter? Journal of Education for Teaching, 45(5), 494-510. https://doi.org/10.1080/02607476.2019.1674560

Goodnough, K., \& Mulcahy, D. (2011). Developing teacher candidate identity in the context of a rural internship. Teaching Education, 22(2), 199-216. https://doi.org/10.1080/10476210.2010.539680

Halsey, J., \& Drummond, A. (2014). Reasons and motivations of school leaders who apply for rural, regional and remote locations in Australia. Australian and International Journal of Rural Education, 24(1), 69-77.

Hay, M., Mercer, A. M., Lichtwark, I., Tran, S., Hodgson, W. C., Aretz, H. T., Armstrong, E. G., \& Gorman, D. (2017). Selecting for a sustainable workforce to meet the future healthcare needs of rural communities in Australia. Advances in Health Sciences Education, 22(2), 533-551. https://doi.org/10.1007/s10459-016-9727-0

Henebery, B. (2020). Schools face 'critical' teacher shortage in 2020. The Educator Magazine. https://www.theeducatoronline.com/k12/news/schools-face-critical-teacher-shortage-in-2020/269422

High demand teaching areas. (2021). Queensland Government: Department of Education. https://teach.qld.gov.au/become-a-teacher/high-demand-teaching-areas

Ingersoll, R. M. (2001). Teacher turnover and teacher shortages: An organisational analysis. American Educational Research Journal, 38(3), 499-534. https://doi.org/10.3102/o0028312038003499

Krivokapic-Skoko, B., Reid, C., \& Collins, J. (2018). Rural cosmopolitism in Australia. Journal of Rural Studies, 64, 153-163. https://doi.org/10.1016/j.jrurstud.2018.01.014

Lent, R. W., \& Brown, S. D. (1996). Social cognitive approach to career development: An overview. The Career Development Quarterly, 44(4), 310-321. https://doi.org/10.1002/j.2161-0045.1996.tboo448.x

Lent, R. W., Brown, S. D., \& Hackett, G. (1994). Toward a unifying social cognitive theory of career and academic interest, choice, and performance. Journal of Vocational Behavior, 45(1), $79-122$. https://doi.org/10.1006/jvbe.1994.1027

Ling, C., \& Tran, L. (2015). Chinese international students in Australia: An insight into their help and information seeking manners. The International Education Journal: Comparative Perspectives, 14(1), 42-56. http://dro.deakin.edu.au/eserv/DU:30074166/tran-chineseinternational-2015.pdf

Merriam, S. B. (2009). Qualitative research: A guide to design and implementation. Jossey Bass. 
Odland, G., \& Ruzicka, M. (2009). An investigation into teacher turnover in schools. Journal of Research in International Education, 8(1), 5-29.

Patty, A. (2021, January 17). Teacher shortage opens gate to country lifestyle. The Sydney Morning Herald. https://www.smh.com.au/business/workplace/teacher-shortage-opens-gate-to-country-lifestyle-20210111p56t86.html

Petrin, R. A., Schafft, K. A., \& Meece, J. L. (2014). Educational sorting and residential aspirations among rural high school students. American Educational Research Journal, 51(2), 294-326. https://doi.org/10.3102/o002831214527493

Pit, S. W., \& Hansen, V. (2014). Factors influencing early retirement intentions in Australian rural general practitioners. Occupational Medicine, 64(4), 297-304. https://doi.org/10.1093/occmed/kquo28

Russell, D. J., Zhao, Y., Guthridge, S., Ramjan, M., Jones, M. P., Humphreys, J. S., \& Wakerman, J. (2017). Patterns of resident health workforce turnover and retention in remote communities of the Northern Territory of Australia, 2013-2015. Human Resources for Health, 15(1), 52. https://doi.org/10.1186/s1296o-017-0229-9

Sakurai, T., McCall-Wolf, F., \& Kashima, E. S. (2010). Building intercultural links: The impact of a multicultural intervention programme on social ties of international students in Australia. International Journal of Intercultural Relations, 34(2), 176-185. https://doi.org/10.1016/j.ijintrel.2009.11.002

Simpson, J., \& Wigglesworth, G. (2019). Language diversity in Indigenous Australia in the 21st century. Current Issues in Language Planning, 20(1), 67-80. https://doi.org/10.1080/14664208.2018.1503389

Strauss, A., \& Corbin, J. M. (1990). Basics of qualitative research: Grounded theory procedures and techniques. Sage.

Tang, K. H., \& Dos Santos, L. M. (2017). A brief discussion and application of interpretative phenomenological analysis in the field of health science and public health. International Journal of Learning and Development, 7(3), 123-132. https://doi.org/10.5296/ijld.v7i3.11494

The Australian education system: Foundation level. (2020). https://www.dfat.gov.au/sites/default/files/australianeducation-system-foundation.pdf

Thomas, D. R. (2006). A general inductive approach for analysing qualitative evaluation data. American Journal of Evaluation, 27(2), 237-246. https://doi.org/10.1177/1098214005283748

Ushioda, E., \& Dornyei, Z. (2017). Beyond global English: Motivation to learn languages in a multicultural world. The Modern Language Journal, 101(3), 451-454. https://doi.org/10.1111/modl.12407

Weiner, L. (2012). The future of our schools: teachers unions and social justice. Haymarket Books.

Weiner, L., \& Jerome, D. (2016). Urban teaching: The essentials (3rd ed.). Teachers College Press.

Weldon, P. (2018). Early career teacher attrition in Australia: Evidence, definition, classification and measurement. Australian Journal of Education, 62(1), 61-78. https://doi.org/10.1177/oo04944117752478

White, S., Lock, G., Hastings, W., Cooper, M., Reid, J.-A., \& Green, W. (2011). Investing in sustainable and resilient rural social space: Lessons for teacher education. Education in Rural Australia, 21(1), 67-78.

Yi, H., Mo, D., Wang, H., Gao, Q., Shi, Y., Wu, P., Abbey, C., \& Rozelle, S. (2018). Do resources matter? Effects of an in-class library project on student independent reading habits in primary schools in rural China. Reading Research Quarterly, 54(3), 383-411. https://doi.org/10.1002/rrq.238 